6-2019

\title{
Wage Boards for the 21st Century: Revisiting Sectoral Standard- Setting Mechanisms for the Workplace
}

\section{Sara Slinn}

Osgoode Hall Law School of York University, sslinn@osgoode.yorku.ca

Follow this and additional works at: https://digitalcommons.osgoode.yorku.ca/conference_papers

Part of the Labor and Employment Law Commons

\section{Recommended Citation}

Slinn, Sara, "Wage Boards for the 21st Century: Revisiting Sectoral Standard-Setting Mechanisms for the Workplace" (2019). Conference Papers. 8.

https://digitalcommons.osgoode.yorku.ca/conference_papers/8

This Conference Proceeding is brought to you for free and open access by the Research Papers, Working Papers, Conference Papers at Osgoode Digital Commons. It has been accepted for inclusion in Conference Papers by an authorized administrator of Osgoode Digital Commons. 


\title{
Round-table on Comparative Perspectives on Collective Bargaining Decentralization, Labour Law Research Network Conference (LLRN 4) Valparaíso, Chile, June 23-25, 2019
}

\section{Wage Boards for the $21^{\text {st }}$ Century: Revisiting Sectoral Standard-Setting Mechanisms for the Workplace}

\author{
Sara Slinn *
}

As existing labour relations and minimum standards regulatory systems have continued to struggle to ensure acceptable worker voice and workplace standards, attention has increasingly turned to whether broader-based or sectoral approaches can offer solutions. Broader-based or sectoral approaches can be understood as falling into three categories of models: multi-employer, juridical extension, and sectoral standard-setting models. A key difference among these is that the first two categories involve not only collective representation of workers but also collective bargaining; the third model - sectoral standardsetting - involves a form of collective representation, but does not involve collective bargaining, which is characterized by compelled recognition, a duty to bargain in good faith, and a duty of fair representation borne by employee representatives. Instead, sectoral standard-setting models involve forms of negotiation and consultation.

In the early $20^{\text {th }}$ century, several countries established statutory systems of sector-based minimum workplace standard-setting as a response to unacceptable wages and working conditions. ${ }^{1}$ Key examples are the British Wages Council system (which developed from the Trade Boards Act, 1909), the 1934 Industrial Standards Act (ISA) established in the Canadian province of Ontario, and the 1938 federal United States Fair Labor Standards Act (FLSA). ${ }^{2}$ Although these three statutory systems arose out of broadly similar social and economic concerns, they reflect different conceptions or applications of tripartism, different perspectives on the role of voluntarism and collective representation and bargaining, and different approaches to sectoral workplace standard-setting. These systems also share important commonalities: all had roots in combatting sweated labour, characterized by fragmented and scattered workplaces and unacceptable remuneration and conditions of work, where - partly due to the characteristics of the work, workers and employers in these sectors - no voluntary collective negotiations could take root. These circumstances have clear parallels to today's work and economy.

This article examines these three systems, at the point at which each regime provided the most robust sectoral standard-setting procedure, as informative examples of a spectrum of approaches to tripartite

\footnotetext{
${ }^{*}$ Associate Professor \& Associate Dean (Research \& Institutional Relations), Osgoode Hall Law School, York University, Toronto.

${ }^{1}$ These were not the first instances of sectoral standard-setting legislation: New Zealand and Australia, for instance, had adopted such legislation in the $19^{\text {th }}$ century. However, these earlier examples are not addressed in this article.

2 Trade Boards Act 1909, 8 Edw. 7 - 9 Edw. 7, c. 22, § 3 (Gr. Brit.) [TBA]; Ontario Industrial Standards Act 1935, S.O. 117, c. 28 [ISA]; Fair Labor Standards Act of 1938, 29 U.S.C.A. § 201-219 (1938) [FLSA].
} 
sectoral workplace standard-setting. Out of this comparison, this article then offers some considerations for a modern approach to sectoral workplace standard-setting. ${ }^{3}$

\section{Statutory Sectoral Standard-Setting Systems}

\section{A. British Wages Councils}

Wages Council legislation underwent numerous amendments between its initial introduction in the early $20^{\text {th }}$ century and its repeal and simultaneous abolition of existing councils in the early $1990 \mathrm{~s}^{4}$ This paper examines the Wages Council system as it existed under the Wages Councils Act 1979, c. 12, ("WCA") which represents the zenith of this system - the point at which Wages Councils had broadest application and greatest authority over terms and conditions of work. The Wages Council system was ultimately repealed, and wages councils mostly abolished in 1993 by the Thatcher government. Essentially the wages council system was replaced by national minimum wage legislation in $1998 .^{5}$

Wages Councils were tripartite bodies composed of independent members, in addition to equal numbers of representative members appointed by employers and by employees, responsible for establishing sector-wide minimum wages and an array of terms and conditions of work. ${ }^{6}$ The WCA had its origins in the Trade Boards Act, 1909, a product of the anti-sweating movement, and out of which the Wages Councils system developed, permitted the government's Board of Trade to establish a board in any industry where wages were "exceptionally low compared with that in other employments". ${ }^{7}$ The Trade Board Act underwent several amendments and a significant reorientation towards regarding trade boards as temporary structures which would develop into and be replaced by joint industrial councils and voluntary collective bargaining once the parties had developed the capacity to do so. As described by one commentator: "One of the objects of wages councils legislation has always been to stimulate collective bargaining, to provide a training ground for voluntary procedure, and to this extent to make the statutory procedure superfluous." 8

The Wages Council Act 1945 repealed the Trade Boards Acts of 1909 and 1918, renamed trade boards as "wages councils", and introduced several changes to the system, but reaffirmed and the role of wages councils as, essentially, filling a gap where voluntary collective bargaining had failed to emerge, and extending this role to supporting inadequate bargaining machinery. ${ }^{9}$

\footnotetext{
${ }^{3}$ For the British Wages Council system, this is as it existed under the Wages Councils Act 1979, 27 Eliz. 2 - 28 Eliz. 2 , c. 12 (Gr. Brit.) [WCA]; for the Ontario ISA, as it existed at the time it was repealed in 2001; and, for the FLSA, as it was first enacted in 1938.

${ }^{4}$ Trade Union Reform and Employment Rights Act 1993, 41 Eliz. 2 - 42 Eliz. 2, c. 19, § 50, sch. 9. Note that, in addition to the WCA, wages councils existed specific to agriculture (Agricultural Wages Act 1948, 12 Geo. 6 - 13 Geo. 6, c. 47, § 17 and the Agricultural Wages (Scotland) Act 1949, 13 Geo. 6 - 14 Geo. 6, c. 30, § 2), and also ultimately abolished, although not until two decades later (Enterprise and Regulatory Reform Act 2013, 61 Eliz. 2 62 Eliz. 2, c. $24, \S 72$ ). However, agricultural wages councils are not considered here: these had analogous structures and virtually the same powers as councils established under the WCA.

${ }^{5}$ Doug Pyper, Business and Transport Section, The National Minimum Wage: historical background 3 (2014). The remaining Agricultural Wages Board, established under that industry-specific wages council legislation, remained in existence until its abolition in 2013.

${ }^{6}$ WCA 1979, supra note 3, § 1 and Sched. 2.

${ }^{7}$ TBA 1909, supra note 2 , § 1(2).

${ }^{8}$ OtTO KAHN-FreUnd ET AL., KAHN-FreUnd's LABOUR AND THE LAW 188 (1983).

${ }^{9}$ Simon Deakin \& Francis Green, One hundred years of British minimum wage legislation, 47 Brit. J. of Indus. Rel. 205, 206 (2009).
} 
Ultimately, under the 1979 Wages Council Act, there were three alternative routes under which the Secretary of State ("SOS") could decide to order that a wages council be established, including on the SOS's initiative or on application by a joint industrial council or jointly by worker and employer organizations. ${ }^{10}$ The overarching theme was that minimum standards were to be set by a wages council only where workers in the sector require a mandated floor, and this is achieved through the different statutory tests applying to each of the three routes:

(1) The most common path to establishment of a wages council was initiated by the SOS where, in his or her opinion (Labour 1961, rev'd. 1964, 155):

$[\mathrm{N}] \mathrm{o}$ adequate machinery exists for the effective regulation of the remuneration of any workers or the existing machinery is likely to cease to exist or be adequate for that purpose and a reasonable standard of remuneration among those workers will not be maintained....

The SOS could then refer to the Advisory, Conciliation and Arbitration Service (ACAS), ${ }^{11}$ the question of whether to establish a wages council. Then, the SOS "if he thinks fit, may on his own motion" choose to give effect to ACAS' recommendation. ${ }^{12}$

(2) The SOS could also initiate establishment of a wages council where, in his or her opinion:

$[\mathrm{N}] \mathrm{o}$ adequate statutory machinery exists for the effective regulation of the remuneration of the workers described in the order and that, having regard to the remuneration existing among those workers, or any of them, it is expedient that such a council should be established. ${ }^{13}$

(3) As a final alternative, organizations of employers and workers, which had routinely participated in the settling wages and conditions of employment in a sector, could jointly apply to the SOS, as could a Joint Industrial Council or another similar body. ${ }^{14}$ These applications had to be made on the ground that:

[T] hat the existing machinery for the settlement of remuneration and conditions of employment for those workers is likely to cease to exist or be adequate for the purpose. ${ }^{15}$

If the SOS was of the opinion that:

$[\mathrm{N}] \mathrm{o}$ adequate machinery exists for the effective regulation of the remuneration of any workers or the existing machinery is likely to cease to exist or be adequate for that purpose and a reasonable standard of remuneration among those workers will not be maintained....

The SOS then could then refer to ACAS the question of whether a wages council should be established and could decide to give effect to ACAS recommendations. ${ }^{16}$

\footnotetext{
${ }^{10}$ WCA 1979 , supra note $3, \S 1$.

${ }^{11}$ ACAS is a government funded, independent, statutory body providing conciliation services and advice and guidance on workplace issues.

${ }^{12}$ WCA 1979, supra note $3, \S \S 1(1)(\mathrm{c}), 3$.

${ }^{13}$ Id. $\S 1(2)(\mathrm{a})$.

${ }^{14} I d . \S \S 1(2)(\mathrm{b}), 2(1)(\mathrm{a}),(\mathrm{b})$.

${ }^{15} I d . \S 2(1)$.

${ }^{16} I d . \S \S 1(1)(\mathrm{b})$ and (c), 3.
} 
The WCA covered "workers", broadly defined to include both contracts of and for service ${ }^{17}$, apprenticeship, and "any other contract whereby [the person] undertakes to do or perform personally any work or services for another party to the contract who is not a professional client of [the person]". Homeworkers were explicitly included, regardless of whether they met the above descriptions; however, casual employment and employment for purpose other than that of the employer's business, were excluded. ${ }^{18}$

Wages councils were tripartite bodies, composed of equal numbers of worker and employer representatives and up to three independent members. Council members were appointed for five-year terms and the SOS provided funding to pay members such remuneration, travelling and other allowances determined by the SOS and government. ${ }^{19}$ While the SOS determined the numbers of representatives, employers' associations and unions directly appointed individuals to fill those positions. ${ }^{20}$ The SOS decided the number of independents and appointed these members, including appointing one independent member to act as chair of the Council. ${ }^{21}$

Independents were intended to operate as tie-breakers should employer and worker representatives reach deadlock. ${ }^{22}$ As described below, the voting procedures established by regulation and applied in wage council decision-making reflects and reinforces this intended role for independents. Independents were apparently typically academics and lawyers rather than industry experts. ${ }^{23}$ Incorporation of independent members has been described as the "chief distinctive feature" of wages councils and the predecessor trade boards, and a key reason for councils' successful operation. ${ }^{24}$

The WCA granted wages councils authority to make orders setting remuneration, holidays and other terms and conditions for all or any of the workers within the council's field of operation, although some restrictions existed relating to holidays. ${ }^{25}$ Therefore, unlike other sectoral standard-setting bodies, wages councils did not merely make recommendations to the government and, in this regard, they exercised tremendous autonomy. However, the SOS did have authority to, at any time, issue an order varying the field of operation of a wages council. ${ }^{26}$

Prior to making an order, a council was required to "make such investigations as it thinks fit", to publish and give notice "for the purpose of informing, so far as practicable, all persons affected" of its proposals, and to consider any written representations regarding proposals. ${ }^{27}$ Further publication and notice

${ }^{17}$ This would likely encompass what, in Canadian labour and employment law, we would classify as "employees", "dependent contractors" and "independent contractors".

${ }^{18}$ WCA 1979, supra note $3, \S 28$.

${ }^{19}$ Id. Sched. 2, $\S 8(1), 9$.

${ }^{20} I d$. $\S 1(2)-(5)$. Prior to 1975 , representative members were nominated by employer and employee organizations but appointed by the SOS.

${ }^{21}$ Id. Schedule 2, § 1(1), (6).

${ }^{22}$ Frederic Joseph BAYliss, BRITISH WAGES COUNCILS 2 (1962); KAHN-Freund, supra note 8, at 185.

${ }^{23}$ KAHN-FREUND, id.

${ }^{24}$ BAYLISS, supra note 22, at 1, 2.

${ }^{25} I d$. $\S 1(1), 14$. Some statutory restrictions existed on orders relating to holidays: id. § 1(2)-(3).

Notably, although earlier legislation provided only for authority to set "wages", over time the statutory scope of wages councils' authority grew as the term "wages" was replaced by "remuneration" and then to include holidays and holiday remuneration, and then to include other terms and conditions of employment (Wages Councils Act 1959, 7 Eliz. 2 - 8 Eliz. 2, c. $69, \S 11)$.

${ }^{26}$ WCA 1979, supra note $3, \S 4(2)$.

${ }^{27}$ Id. § 14(4)-(6). 
of any modifications to proposals would be given where the council modified its proposals and "it appears to the councils that, having regard to the nature of any proposed modifications, an opportunity should be given to persons concerned to consider the modifications". ${ }^{28}$ Where a council made an order, giving effect to a proposal, notice of the order was to be given to all persons affected by it, "as far as practicable". ${ }^{29}$ Wages councils' orders, reportedly, were based on comparisons with bargained outcomes for similar services in other industries, rather than on abstract assessments of minimum standards. ${ }^{30}$

Wages councils made decisions regarding orders by vote, and the determined their own procedures, except where the WCA or regulations provided otherwise. ${ }^{31}$ Regulations stipulated that each council member had one vote, and provided that either if the chair decided, or more than half the representative members for employers or workers requested, then a "voting by sides" procedure would be followed. Under this procedure the majority of members' votes on each of the employer and worker "sides" will determine the vote of that side. Independent members would then only vote where the two sides disagree. ${ }^{32}$ Orders were legally enforceable, subject to government inspections and the potential for criminal prosecution. ${ }^{33}$ In addition, terms of orders were implied into contracts of employment and, therefore, could also be enforced through civil actions. ${ }^{34}$

Wages councils were not, however, intended to be permanent bodies. Reflecting the long-standing philosophy that wages councils were to be temporary solutions to a lack of collective bargaining, or supports to faltering collective bargaining, the WCA provided for abolition of wages councils in certain circumstances.

A wages council could be abolished in one of two ways. First, the SOS could order that a wages council be abolished, on his own motion, and could refer the question to the ACAS of whether it should be abolished or its field of operation varied, and the ACAS may make investigations. ${ }^{35}$ In such cases the SOS was required to refer the question to ACAS of whether the wages council should be abolished or its field of operation varied. ${ }^{36}$ Alternatively, the SOS could order that a wages council be abolished where the SOS has received an application from either: organizations of works and organizations of employers, jointly (s.5(1)(b)); any organization of workers (s. 5(1)(c)); or, a joint industrial council, conciliation board or other similar body of workers or employers(9s.5(1)(a)), where the applicant "represents a substantial proportion of the workers with respect to whom that wages council operates" and on the grounds "that the existence of a wages council is no longer necessary for the purpose of maintaining a reasonable standard of remuneration for the workers with respect to whom that wages council operates." ${ }^{37}$ Here, the SOS was not required, but could choose, whether to refer the abolition or variance of field of operation questions to ACAS. $^{38}$

\footnotetext{
${ }^{28} I d . \S 14(4)-(6)$.

${ }^{29} I d . \S 14(9)$.

${ }^{30}$ Deakin and Green, supra note 9, at 207.

${ }^{31}$ WCA 1979, supra note 3, Sched. 2, § 7.

${ }^{32}$ Wages Councils (Meetings and Procedure) Regulations 1975, 1975 No. 2136, $§ 3$ (Gr. Brit.).

${ }^{33}$ WCA 1979, supra note 3, § 15 and Part IV (§§ 21-24).

${ }^{34}$ Employment Protection Act 1975, 1975 c. 71, § 109(8)(a), (b) (Gr. Brit.) [EPA].

${ }^{35}$ WCA 1979, supra note $3, \S \S 4(1)(b), 6,7$.

${ }^{36} \mathrm{Id} . \S \S 4(1)(\mathrm{b}), 6,7$.

${ }^{37}$ Id. $\S 4(1)(\mathrm{a}), 5-7$.

${ }^{38} I d . \S 4(1)(b), 6,7$.
} 
In addition, amendments to the WCA by the Employment Protection Act 1975 created what has been labeled a "half way house" to collective bargaining: statutory joint industrial councils. ${ }^{39}$ The SOS could order that a wages council become a JIC, and having the functions set out in Part III of the WCA (that is, the same powers as a wages council to make orders regulating terms and conditions of work). ${ }^{40}$ Described as "a hybrid creature, sharing some features with a statutory wages council and some with a voluntary negotiating body" JICs were composed of employer and employee representatives (no independent members), but had authority to issue enforceable orders as did wages councils. ${ }^{41} \mathrm{JICs}$ could request assistance from ACAS, to essentially act as independents would act in a wages council, if it could not settle a matter. However, statutory JICs, themselves, were also intended to be temporary, to be abolished once employers and employees were capable of voluntary bargaining.

\section{B. Ontario Industrial Standards Act}

Ontario's Industrial Standards Act provided for tripartite bodies consisting of employee, employer and government representatives to be established for individual sectors, defined on industry and geographic dimensions, to negotiate wages and working conditions that, if accepted by the government would become enforceable minimum standards applying to all employers and employees in the sector.

Passed in 1935, the ISA was the product of myriad influences, including recent federal and provincial government inquiries into competition in particular industries, with attention given to evidence of excessive competition and unacceptable wage and labour standards in those industries, ${ }^{42}$ and legislation in other jurisdictions providing for establishment of industrial or trade codes setting minimum standards ${ }^{43}$ or juridical extension of collective agreements. ${ }^{44}$ The public had been pressuring Canadian governments to adopt fair wages and price codes, as had recently been established by the US National Industrial Recovery Act, and some businesses sought curbs on unfair competition. ${ }^{45}$ Meanwhile, the labour movement lacked consensus at that time on the issue of statutory minimum wages. Some unions, although supportive of such legislation, were concerned that minimum standards might, in effect, define the wage ceiling. Others regarded such legislation as a threat to the role of unions. ${ }^{46}$

The year after the ISA was introduced it underwent review and was substantially amended in 1936 and 1937, with the key effect of clearly reorienting the legislation from "fair wage" to "minimum standards"

\footnotetext{
39 EPA 1975, supra, note 34, $\S 90-94$ and Sched. 8. KAHN-FREUND, supra note 8, at 188.

${ }^{40}$ WCA 1979, supra note 3, §19(1).

${ }^{41}$ KAHN-FREUND, supra note 8, at 188.

42 These inquiries were the 1934 Select Special House of Commons Committee on Price Spreads and Mass Buying which led to the Royal Commission on Price Spreads and the 1934 Standing Committee on Labour of the Ontario Legislative Assembly 1934.

43 Alberta Department of Trade and Industry Act S.A. 1934, c. 33; National Industrial Recovery Act 1933 , 15 U.S.C. $\S 703$ [NIRA].

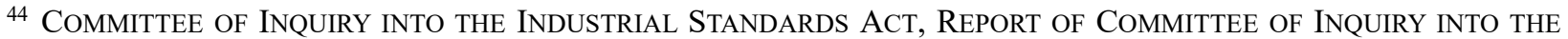
INDUSTRIAL STANDARDS ACT 4-6 (1963). Interestingly, these included the Quebec Collective Labour Agreements Extension Act, Q.C. 1934, c. 56 and the Cotton Manufacturing Industry (Temporary Provisions) Act 1934, 24 Geo. 5 - 25 Geo. 5, c. 30 (Gr. Brit.), which amended the British Trade Boards Act. The Trade Boards Act, itself, is not identified by commentators as one of the ISA's influences.

${ }^{45}$ LaUrel Sefton MacDowell, Renegade LAWYer: The LifE OF JL COHEN 68 (2002).

${ }^{46} I d$.
} 
regulation in nature. ${ }^{47}$ It was later substantially reviewed and amended in the early 1960 s to, among other things, strengthen enforcement, broaden the range of regulated matters, administration, and definitions and alterations to sectors, then it was ultimately repealed in 2001 in the context of comprehensive amendments to the province's Employment Standards Act. ${ }^{48}$ Note that the following description of the ISA system reflects the legislation as it existed at the time of its repeal in $2001{ }^{49}$

The ISA offered a tripartite mechanism for sectoral regulation of wages and working conditions through "schedules" which applied to all employers and employees in a "zone" encompassing a particular industry within a specified geographic area ${ }^{50}$ For industries subject to inter-provincial competition, zones were province-wide in scope. ${ }^{51}$ Utilizing a broad definition of "employee", based on a worker being "in receipt of or entitled to wages", the Act covered nonstandard workers and, specifically, included situations where the same person was an employee for one purpose and an employer for another under the Act. ${ }^{52}$

The notion of tripartism incorporated in the ISA involved representation for employees, employers and the government. While the ISA included no mention of trade unions or collective agreements, unions commonly acted as employee representatives under the Act. ${ }^{53}$

The standard-setting process was initiated by employers or employees in an industry - not by the government or Minister - within a particular region of the province, or anywhere in the province, petitioning the Minister of Labour to convene a "conference". If the Minister accepted the petition, he would authorise an industrial standards officer (ISO) to convene a conference, at which employer and employee representatives would try to negotiate a "schedule" of matters relating minimum workplace standards. ${ }^{54}$ The ISO acted as the representative of the Minister and government at these conferences. Schedules could include wages, hours of work, working days, vacation pay and overtime limits and overtime. ${ }^{55}$ The resulting schedules were often based on collective agreements that existed in the relevant industry. ${ }^{56}$

Conference negotiations were not in the nature of collective bargaining. Described as a "wholly permissive statute, ${ }^{, 57}$ employer representatives were not compelled to participate or to reach agreement, and the ISA provided no dispute resolution mechanism, nor did it impose a good faith obligation on representatives.

\footnotetext{
${ }^{47}$ Mark Cox, The Limits of Reform: Industrial Regulation and Management Rights in Ontario, 1930-7, 68 CANADIAN HIST. REV. 552, 572-573 (1987).

48 Ontario An Act to amend The Industrial Standards Act 1935, S.O. 1937, c. 32; Ontario An Act to amend The Industrial Standards Act 1935, S.O. 1936, c. 29. Repealed effective September 4, 2001: Employment Standards Act, 2000, S.O. 2000 , c. $41, \S \S 144$ (5), 145).

${ }^{49}$ Ontario, Industrial Standards Act, R.S.O. 1990, c. I.6 [ISA 1990].

${ }^{50} I d . \S \S 5,6$; Designation of Industries and Zones, O. Reg. 296/01 (Can.).

${ }^{51}$ Id. $\S 7(1)(\mathrm{e})$; Interprovincially Competitive Industries, O. Reg. 295/01 (Can.). Note that ISA $\S 23$ prohibited schedules from applying to the agriculture and mining industries.

${ }^{52}$ Id. $\S \S 1,12$.

${ }^{53}$ COMMITTEE OF INQUiRY INTO THE INDUSTRIAL STANDARDS ACT, supra note 44, at 1.

${ }^{54}$ ISA 1990, supra note $49, \S \S 5,8(1)$.

${ }^{55}$ Id. $\S \S 8,9$.

${ }^{56}$ Jonathan B. Eaton, Labour law reform for the new workplace: Bill 40 and beyond, 342 (1994) (LLM dissertation).

${ }^{57}$ COMMITTEE OF INQUiRY INTO THE INDUSTRIAL STANDARDS ACT, supra note 44, at 1.
} 
Where the representatives were able to agree on a proposed schedule, the conference would submit it to the Minister through the ISO who had convened the conference. ${ }^{58}$ The state-involvement element of the tripartite character of ISA standard-setting appeared to largely take place outside of and following the conference negotiations and seemed to grant the state significant scope to unilaterally shape schedules. The Minister could direct the ISO to investigate labour conditions and practices in the industry, and the ISO could recommend variations to the proposed schedule. ${ }^{59}$ The Minister had authority to approve the proposed schedule if it had been approved by a "proper and sufficient representation of employers and employees" in the conference, "with such variations recommended by the [ISO] as the Minister considers desirable". ${ }^{\circ}$ Schedules that the Minister recommended to the Lieutenant in Council could be enacted as regulations in force "during pleasure" and applied to all employers and employees in the designated industry and zone. ${ }^{61}$ Thereafter, the Director of Labour Standards in the Ministry of Labour had authority to unilaterally amend schedules $^{62}$ although in practice employer and employee representatives had input into such changes. ${ }^{63}$

In addition to establishing an array of minimum standards through enacted schedules, the ISA required employers subject to a schedule to keep records and to make them available for inspection. ${ }^{64}$ The ISA also provided protection for employees against retaliation and reinstatement as a possible remedy. It prohibited termination of threats of termination or discrimination against employees for testifying in ISA proceedings or participating in investigations. Remedies included reinstatement orders, which could include compensation for lost earnings and other employment benefits. These orders could be filed by the employee in superior court permitting the employee to pursue contempt proceedings for noncompliance, and these orders were not to be stayed where the employer appealed. ${ }^{65}$

The tripartite conference process could be succeeded by a bipartite committee, an "Advisory Committee", which would be formally responsible for administering and enforcing enacted schedules. This occurred where the approved schedule designated an advisory committee to assist in administration. ${ }^{66}$ In such cases, an Advisory Committee could be established by the Minister for each zone or group of zones for which a schedule had been approved. Advisory Committees were bipartite - not tripartite - bodies, composed of up to five members from employer and employee sides, serving three-year terms although the legislation did not set out the proportion of employer and employee representatives. Required to meet regularly, and at least once every three months, and Committee members' expenses were paid by government. ${ }^{67}$

\footnotetext{
${ }^{58}$ ISA 1990 , supra note $49, \S 8(2)$.

${ }^{59}$ Id. $\S 10(1)$.

${ }^{60} I d . \S 10(2)$.

${ }^{61} \mathrm{Id} . \S 10(3)$.

${ }^{62} \operatorname{Id} . \S 7(1)(\mathrm{c})$.

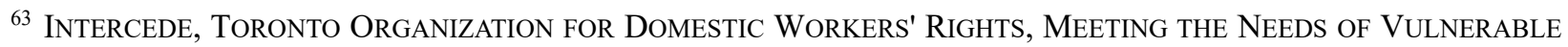
WORKERS: PROPOSALS FOR IMPROVED EMPLOYMENT LEGISLATION AND ACCESS TO COLLECTIVE BARGAINING FOR DOMESTIC WORKERS AND INDUSTRIAL HOMEWORKERS (1993).

${ }^{64}$ ISA 1990, supra note 49, § 13; Ontario Duties of Employers and Advisory Committees, R.R.O. 1990, Reg. 652, § 2 [DEAC].

${ }^{65}$ ISA 1990, id. $\S \S 19-21$.

${ }^{66}$ Id. § 18(1). JOHN D. MCCAMUS, ONTARIO LAW REFORM COMMISSION, REPORT ON AVOIDING DELAY AND MULTIPLE PROCEEDINGS IN THE ADJUDICATION OF WORKPLACE DISPUTES 34 (1995).

${ }^{67}$ Id. § 18; DEAC, supra note $64, \S 16$.
} 
Where an Advisory Committees was established, it could hear employer and employee complaints, could hire inspectors to investigate and enforce violations. These Committees had significant, particular, powers including the authority to issue permits for overtime work and to set a minimum wage rate that was below the rate set out in the schedule. ${ }^{68}$ Decisions of Advisory Committees could be appealed to the Director of Labour Standards for a final decision. ${ }^{69}$ Although not a statutory responsibility of Advisory Committee, it was the practice for Committees to make recommendations to the Minister about revising schedules. ${ }^{70}$ Where an Advisory Committee was not established, the Director of Labour Standards remained responsible for administrative decisions about enacted schedules. ${ }^{71}$

While the ISA lacked any form of compulsion with respect to establishing schedules, it did provide for enforcement of approved schedules. However, enforcement was not in the hands of Advisory Committees or the Ministry. Instead, violations of a schedule, order to pay wages, or the prohibition on retaliation, could only be prosecuted as provincial offences, requiring consent to prosecute from the Director of Labour Standards, and which could result in substantial fines and the possibility of imprisonment. $^{72}$

The structure of the ISA has been criticized as having several important shortcomings. In terms of composition and participation, the ISA did not address the proportion of employer and employee representation at conferences or advisory committees, ${ }^{73}$ nor did it include any means for compelling or encouraging participation - particularly by employers. ${ }^{74}$ Further, the Act provided no mechanism for breaking deadlocks in conference negotiations. ${ }^{75}$ Some commentators contend the ISA gave too much discretion to the Minister over the content of schedules ${ }^{76}$ and too much power to change schedules. ${ }^{77}$ Moreover, there were long delays in approving and enacting schedules, with the result that schedules could be out of date by the time they approved by the Minister. ${ }^{78}$

\section{Fair Labor Standards Act}

Enacted by the US federal government in 1938, the Fair Labor Standards Act provided for minimum wage rates, overtime pay and protections for child labour for public and private sector workers. ${ }^{79}$ The legislation

${ }^{68}$ ISA 1990 id. $\S \S 9(2), 18(4)$.

${ }^{69}$ Id. $\S \S 18$; DEAC, supra note $64, \S \S 5-10,13$.

${ }^{70}$ INTERCEDE, supra, note 63, at 33.

${ }^{71}$ MCCAMUS, supra note 66.

${ }^{72}$ ISA 1990 , supra note $49, \S \S 19-21$. Violation of a schedule could result in a maximum fine of $\$ 50,000$ for employers and \$2000 for employees, upon conviction. If an employer defaulted on a fine, this could result in imprisonment for up to six months. An employer convicted of violating minimum wage rates were subject to an order to pay the Director of Labour Standards the amount of unpaid wages as a penalty in addition to any fine. It was at the Director's discretion whether to direct all or part of the penalty amount to be forfeited to the Crown or to the relevant employee. The Director could also file a copy of an order for payment of wages in Superior court, or small claims court.

${ }^{73}$ INTERCEDE, supra, note 63, at 33.

${ }^{74}$ JUdY FUdGE, ERIC TUCKER, \& LEAH VOSKO, THE LEGAL CONCEPT OF EMPLOYMENT: MARGINALIZING WORKERS 272 (2002).

${ }^{75}$ INTERCEDE, supra, note 63, at 33.

${ }^{76}$ EATON, supra note 56, at 346.

${ }^{77}$ INTERCEDE, supra, note 63, at 33.

${ }^{78} I d$.

${ }^{79}$ FLSA 1938, supra note $2, \S 18$ (where a state enacted minimum standards legislation providing greater protection than the FLSA, the state law governed). 
required that tripartite "industry committees" be established "for each industry engaged in commerce or in the production of goods for commerce", to recommend minimum wages for the relevant industry, within limits established by the FLSA ${ }^{80}$ Although the FLSA remains in force, it has declined in prominence, with industry committees no longer used. Therefore, this article addresses the early FLSA, as originally introduced in 1938.

The FLSA was not the first minimum wage legislation in the United States, nor the first use of "wage boards". For many decades before FLSA was passed there had been attempts to achieve state legislation addressing hours of work. ${ }^{81}$ Beginning in 1912, and prompted by dire economic and social conditions of many workers as well as by a series of federal and state government reports on inadequate wages and working standards, several states passed minimum wage laws ${ }^{82}$ Nordlund describes three basic approaches taken by this state-level legislation: a statutory flat minimum wage rate applying to all workers; creation of a commission to recommend minimum wage rates based on consideration of a living wage and business conditions, which covered women and children only, and which was not compulsory; and, most commonly adopted, was a version of the second approach which considered only living wage and which produced compulsory, enforced minimum rates. ${ }^{83}$ The Depression provided further motivation for the FLSA, and the short-lived National Industrial Recovery Act (NIRA), the associated National Recovery Administration, and the corporate codes (which included minimum wage standards) established and administered under that system, were influential forerunners to the FLSA. ${ }^{84}$

Given the apparent influence of the NIRA on the FLSA, and the distinction between collective bargaining under the 1935 National Labour Relations Act and the type of non-bargaining collective regulation provided by NIRA, it appears that the FLSA was also intended to play a role in labour and employment regulation that was distinct from that of collective bargaining regulation.

The FLSA's definitions of "employee", "employer" and "employ" are broad, and distinctly broader than similar definitions in contemporary Canadian minimum standards legislation and common law definitions of these terms. ${ }^{85}$ These definitions turn on the definition of "employer", which explicitly contemplated including both direct and indirect relationships, with "employ" defined as "includes to suffer or permit to work". "Employee" was simply defined as "includes any individual employed by an employer." Based on a review of the FLSA's legislative history of the FLSA, Professor Kati Griffith contends that these broad definitions were intentional. ${ }^{86}$ She argues that that legislators understood and foresaw the dangers of narrow definitions which might permit or encourage businesses to "splinter" or "fissure" their operations to avoid the statute. Moreover, legislators anticipated changing business structures and relationships over time. In Griffith's view:

\footnotetext{
${ }^{80} I d . \S 5(\mathrm{a})$.

${ }^{81}$ Luke Norris, The Workers' Constitution, 87 FordHAM L. REV. 1459 (2018).

${ }^{82}$ Willis J. Nordlund, A brief history of the Fair Labor Standards Act, 39 LAB. L. J. 715, 716 (1988).

${ }^{83}$ Id. at 718.

${ }^{84}$ NIRA, supra, note 43; Nordlund, id.

${ }^{85}$ FLSA 1938, supra note 2, $\S 3$ provides: “(d) 'Employer' includes any person acting directly or indirectly in the interest of an employer in relation to an employee but shall not include the United States or any State or political subdivision of a State, or any labor organization (other than when acting as an employer), or anyone acting in the capacity of officer or agent of such labor organization. (e) 'Employee' includes any individual employed by an employer...(g) 'Employ' includes to suffer or permit to work."

${ }^{86}$ Kati L. Griffith, The Fair Labor Standards Act at 80: Everything Old is New Again, 104 Cornell L. Rev. 101, 134-135 (2019).
} 
$[T]$ he message that the legislative history communicates is that the FLSA's regulatory power should reach all businesses responsible, directly or indirectly, for baseline wage standards, regardless of the forms those businesses take, or of the self-serving formalities they impose. ${ }^{87}$

In particular, she points out that there is no reference to the concept of "control" as a factor for determining scope of application in either the text of the FLSA or its legislative history, and contents that the original understandings and intention of these FLSA definitions should be applied today to assist with applying FLSA standards to evolving and fissured business arrangements. ${ }^{88}$

The FLSA provided a Presidentially-appointed Administrator to direct the newly-created Wage and Hour Division in the Department of Labor. ${ }^{89}$ Then, "As soon as practicable" thereafter, the Administrator was to appoint an Industry Committee "for each industry engaged in commerce or in the production of goods for commerce." "Industry Committees were tripartite - composed of equal numbers of "disinterested persons representing the public", employers and employees in the industry. However, the number of representatives was not specified. In appointing Committee members, the Administrator was directed to give due regard to the geographic regions in which the industry is carried on. ${ }^{91}$ One of the public representatives was designated as chair by the Administrator. Committee members were reimbursed for expenses and a given per diem payment. The Administrator was required to provide Committees with "adequate" legal and office. ${ }^{92}$ Commentators noted that, Industry Committees were often large and that this large size was an impediment, yet significant concerns existed about the true representativeness of different unions, non-union workers, organized and unorganized employers, public members, and different geographic industrial regions, on these Committees. ${ }^{93}$ Appointing employee representatives reflecting the relevance of different trade unions and also providing for sufficient representation for unorganized workers were recognized as challenges early on. The Administrator sought to appoint unionist Committee members proportionate to the relative strength of the relevant union. ${ }^{94}$ However, Golding noted that "Any failure to achieve proportional representation has been of little significance since representatives of different unions have always agreed on the wage determinations which should be adopted." ${ }^{\prime 5}$ At least in the early period, the Administrator concluded that union officials were appropriate representatives of unorganized workers on Committees. ${ }^{96}$

The basic task of Industry Committees was to make recommendations to the Administrator about minimum wage rates which would inform resulting Wage Orders. ${ }^{97}$ Recommendations could be made for the industry as a whole, or the Committee could recommend reasonable classifications within an industry, provided that these classifications: "(1) will not substantially curtail employment in such classification and

\footnotetext{
${ }^{87} \mathrm{Id}$. at $133-134$, footnote 14 .

${ }^{88} \mathrm{Id}$. at 134,149 . Griffith also points out that this is contrary to the contemporary interpretation of the FLSA.

${ }^{89}$ FLSA 1938, supra note $2, \S 4$.

${ }^{90} I d . \S 5(\mathrm{a})$.

${ }^{91} I d . \S 5(\mathrm{~b})$.

${ }^{92} \mathrm{Id} . \S 5(\mathrm{c})$

${ }^{93}$ Elroy D. Golding, The Industry Committee Provisions of the Fair Labor Standards Act, 50 THE YALE LAW JouRNAL, 1157-1160 (1941); Z. Clark Dickinson, The Organization and Functioning of Industry Committees under the Fair Labor Standards Act, 6 LAW AND CONTEMPORARY PROBLEMS, 356, 362-367 (1939).

${ }^{94}$ Golding, supra note 93, at 1157.

${ }^{95} \mathrm{Id}$.

${ }^{96} I d$.

${ }^{97}$ FLSA 1938 , supra note $2, \S 8$.
} 
(2) will not give a competitive advantage to any group in the industry, and shall recommend for each classification in the industry the highest minimum wage rate which the committee determines will not substantially curtail employment in such classification." ${ }^{98}$ Moreover, classifications on the basis of age or sex were prohibited. ${ }^{99}$

On convening an Industry Committee, the Administrator would refer to it the question of the minimum wage rate or rates to apply to the industry. The Committee was to investigate conditions in the industry, and this could include hearing witnesses and other evidence. Based on these investigations the Committee would make a recommendation to the Administrator about the "highest minimum wage rates for the industry which it determines, having due regard to economic and competitive conditions, will not substantially curtail employment in the industry." 100

The Administrator was required to provide Industry Committees with "such data as he may have available on the matters referred to it, and shall cause to be brought before it in connection with such matters any witnesses whom he deems material." Industry Committees could also "summon other witnesses or call upon the Administrator to furnish additional information to aid it in its deliberations." 101

The key constraint on Committees' recommendations was the statutory requirement to avoid "substantially curtailing employment". ${ }^{102}$ Quorum was two-thirds of the members of the Industry Committee, and decisions were taken by a vote of "note less than a majority of all its members." 103 It appears that lack of consensus among Committee members was not a significant problem, with reports that in more than half the cases, recommendations were unanimously supported by Committee members. ${ }^{104}$ There is no indication that public interest members were intended to perform the tie-breaking role of independent members of British Wages Councils.

Committee recommendations were contained in reports filed with the Administrator who would then give notice to interested parties who had an opportunity to be heard on the recommendations. Thereafter, if the Administrator "finds that the recommendations are made in accordance with the law, are supported by the evidence adduced at the hearing, and, taking into consideration the same factors as are

\footnotetext{
${ }^{98} I d . \S 8(\mathrm{c})$.
}

The FLSA also specified several mandatory considerations for both Committees and the Administrator in deciding whether and how many classifications to make in any industry. These considerations were:

“(1) competitive conditions as affected by transportation, living and production costs;

(2) the wages established for work or like or comparable character by collective labor agreements negotiated between employers and employees by representatives of their own choosing; and

(3) the wages paid for work of like or comparable character by employers who voluntarily maintain minimum-wage standards in the industry." Id. §8(c).

${ }^{99} \mathrm{Id} . \S 8(\mathrm{c})$.

${ }^{100} I d . \S 8(\mathrm{~b})$.

${ }^{101} I d . \S 5(\mathrm{~d})$.

${ }^{102}$ Id. $\S 8(\mathrm{a})$. This subsection provided: "With a view to carrying out the policy of this Act by reaching, as rapidly as is economically feasible without substantially curtailing employment, the objective of a universal minimum wage of 40 cents an hour in each industry engaged in commerce or in the production of goods for commerce, the Administrator shall from time to time convene the industry committee for each such industry and the industry committee shall from time to time recommend the minimum rate or rates of wages to be paid under section 6 by employers engaged in commerce or in the production of goods for commerce in such industry or classifications therein."

${ }^{103} I d . \S 5(\mathrm{c})$.

${ }^{104}$ Nordlund, supra note 82 , at 723. 
required to be considered by the industry committee, will carry out the purposes of this section; otherwise he shall disapprove such recommendations."

Where the Administrator did not approve a Committee's recommendation, the Administrator was required to refer the matter back to the Committee, "or to another industry committee (which he may appoint for the purpose), for further consideration and recommendation."106

Wage Orders took effect after publication in the Federal Register, ${ }^{107}$ and were to expire after seven years after the effective date of $\S 6$ of the FLSA, and no order was to be issued thereafter or after expiry for an industry "unless the industry committee by a preponderance of the evidence before it recommends, and the Administrator by a preponderance of the evidence adduced at the hearing finds, that the continued effectiveness or the issuance of the order, as the case may be, is necessary in order to prevent substantial curtailment of employment in the industry." 108 Wage Orders could be challenged by "any person aggrieved" by the order, by way of judicial review, although the scope for review was limited by the statute. ${ }^{109}$

Wage Orders were enforceable in the courts, with substantial fines available and, in the case of subsequent offences, the potential for both fines and imprisonment for not more than six months. Employers would also be liable to affected employees for both the amount of the unpaid minimum wage and an additional equal amount as liquidated damages, as well as a reasonable attorney fee and costs of the action. $^{110}$

\section{Constituting a Sectoral Standard-Setting Mechanism}

The preceding outline of three different approaches to sectoral standard-setting mechanism for the workplace (British wages councils, Ontario's Industrial Standards conferences, and FLSA wage boards in the US) prompts three sets of considerations. First, whether to adopt a sectoral standard-setting approach to establishing terms and conditions of work, is a question that is outside the scope of this article. Second, if a workplace standard-setting mechanism is to be adopted, where should it be conceptually located within the overall labour/industrial/workplace relations system. Finally, consideration of whether these early models are instructive in terms of how a sectoral standard-setting mechanism addressing today's workplaces might be configured. A comparative examination of key elements of the three approaches may be helpful to this enquiry (also see Table 1, below).

\footnotetext{
${ }^{105}$ FLSA 1938, supra note $2, \S 8(\mathrm{~d})$.

${ }^{106} I d . \S 8(\mathrm{~d})$.

${ }^{107}$ Id. $\S 8(\mathrm{f})$.

${ }^{108} I d . \S 8(\mathrm{e})$.

${ }^{109}$ Id. $\S 10$.

${ }^{110}$ Id. $\S 16$.
} 
Table 1: Comparison of Sectoral Standard-Setting Models: Wages Councils, ISA Conferences, and Wage Boards

\begin{tabular}{|c|c|c|c|c|c|c|c|c|}
\hline & $\begin{array}{l}\text { Dispute } \\
\text { resolution } \\
\text { mechanism }\end{array}$ & Tripartite form & $\begin{array}{l}\text { Autonomy I } \\
\text { role of state }\end{array}$ & $\begin{array}{l}\text { Scope - } \\
\text { employee }\end{array}$ & $\begin{array}{l}\text { Scope- } \\
\text { employer }\end{array}$ & Scope - topics & $\begin{array}{l}\text { Gradation / } \\
\text { Development }\end{array}$ & Enforcement \\
\hline $\begin{array}{l}\text { UK Wages } \\
\text { Councils }\end{array}$ & $\begin{array}{l}\text { Independent } \\
\text { members / } \\
\text { vote by sides } \\
\text { procedure }\end{array}$ & $\begin{array}{l}\text { Worker } \\
\text { representatives } \\
\text { Employer } \\
\text { representatives } \\
\text { Independents }\end{array}$ & $\begin{array}{l}\text { Wages } \\
\text { Councils had } \\
\text { authority to } \\
\text { issue orders }\end{array}$ & $\begin{array}{l}\text { Worker - } \\
\text { broadly defined }\end{array}$ & $\begin{array}{l}\text { Reflected in } \\
\text { definition of } \\
\text { worker }\end{array}$ & $\begin{array}{l}\text { Remuneration } \\
\text { and terms and } \\
\text { conditions. } \\
\text { Some limits } \\
\text { relating to } \\
\text { holidays. }\end{array}$ & $\begin{array}{l}\text { Joint Industrial } \\
\text { Councils / } \\
\text { abolition }\end{array}$ & $\begin{array}{l}\text { By Wages } \\
\text { Councils, } \\
\text { criminal and } \\
\text { civil actions }\end{array}$ \\
\hline $\begin{array}{l}\text { ISA } \\
\text { Conferences }\end{array}$ & None & $\begin{array}{l}\text { Employee } \\
\text { representatives } \\
\text { Employer } \\
\text { representatives } \\
\text { Government } \\
\text { representative }\end{array}$ & $\begin{array}{l}\text { Proposed } \\
\text { schedules } \\
\text { submitted to } \\
\text { Minister, who } \\
\text { had unilateral } \\
\text { authority to } \\
\text { accept and } \\
\text { modify }\end{array}$ & Employee & $\begin{array}{l}\text { Broad } \\
\text { definition - but } \\
\text { no joint liability }\end{array}$ & $\begin{array}{l}\text { Wages, hours } \\
\text { of work, } \\
\text { working days, } \\
\text { vacation pay } \\
\text { and overtime } \\
\text { limits and } \\
\text { overtime. }\end{array}$ & $\begin{array}{l}\text { Advisory } \\
\text { Committees }\end{array}$ & $\begin{array}{l}\text { By way of } \\
\text { provincial } \\
\text { offences }\end{array}$ \\
\hline $\begin{array}{l}\text { US Federal } \\
\text { Wage Boards }\end{array}$ & $\begin{array}{l}\text { None } \\
\text { Board could be } \\
\text { dissolved and } \\
\text { replaced by } \\
\text { new board }\end{array}$ & $\begin{array}{l}\text { Employee } \\
\text { representative } \\
\text { Employer } \\
\text { representatives } \\
\text { Public } \\
\text { members }\end{array}$ & $\begin{array}{l}\text { Power of } \\
\text { recommendati } \\
\text { on }\end{array}$ & $\begin{array}{l}\text { Employee- } \\
\text { broadly defined }\end{array}$ & $\begin{array}{l}\text { Broad } \\
\text { definition - } \\
\text { including joint } \\
\text { liability }\end{array}$ & $\begin{array}{l}\text { Minimum } \\
\text { wages }\end{array}$ & None & Civil courts \\
\hline
\end{tabular}




\section{A. Conceptual Location}

One set of considerations is where a sectoral standard-setting mechanism would be located within the overall system of workplace regulation, involving collective bargaining, individual negotiations and direct standard-setting by the state, and whether to design it as a permanent mechanism, or as a temporary support to assist employers and employees and the organizations to gain capacity to shift to more independent forms of standard-setting such as voluntary negotiations or collective bargaining. Workplace regulation involving successive, "staged", 112 "graduated", ${ }^{113}$ or "gradated"114 of collective representation and bargaining, as it has variously been labelled, have appeared in the literature for many years. Some explicitly link staged or gradated access to representation and bargaining at the workplace to sectoral level representation, negotiation and bargaining. ${ }^{115}$

One commentator has described the role of wages councils as "a hybrid form between statutory wage regulation and voluntary bargaining." ${ }^{116}$ Howell characterizes the wages council system as an example of "the now familiar role of the British state in creating or encouraging industry bargaining institutions rather than directly regulating outcomes"117 and describes a "hierarchy" of industry-level bargaining systems, including: voluntary collective bargaining covered industries where labor and employers were sufficiently organized; an extension procedure provided an additional enforcement mechanism for industry agreements; ${ }^{118}$ and wages councils, which mimicked collective bargaining, operated in industries where industrial actors were too weakly organized to create voluntary bargaining." 119 JICs were located between wages councils and traditional collective bargaining in this spectrum. Wages councils and JICs were conceived of transitional bodies, and as means to launch parties into independent, collective standard-setting, whether that be in the form of voluntary collective bargaining or non-bargaining collective negotiations and to supplement the collective bargaining system.

In contrast, the ISA system was intended not to be a supplement to the collective bargaining system but to operate as a parallel system, with no explicit role for unions or collective bargaining. Although it did provide for development of conferences into advisory committees, this was not regarded as either a means of developing independent negotiations or collective bargaining capacity for employer and employee representatives. Meanwhile, the FLSA explicitly mentions unions and, while it intended wage boards to be temporary bodies, this temporariness was of a different character than under either the wages council or ISA systems. The FLSA did not provide any form of staged development towards independent standard-

\footnotetext{
${ }^{112}$ Keith D. Ewing, Trade union recognition: a framework for discussion, 19 INDUS. L. J. 209 (1990); KeITH D. EwING \& JOHN HENDY, RECONSTRUCTION AFTER THE CRISIS: A MANIFESTO FOR COLLECTIVE bargaining (2013).

113 Mark Thompson, Wagnerism in Canada: Compared to What? ProceEdings of tHE XXXIsT ConferenceCANADIAN INDUSTRIAL RELATIONS ASSOCIATION, 59-71 (1995); David J. Doorey, Graduated Freedom of Association: Worker Voice Beyond the Wagner Model, 38 QuEEN's L.J. 511 (2012-2013).

114 Jean Bernier, Guylaine Vallée, \& Carol Jobin, Les Besoins de PROtection sociale des Personnes en SITUATION DE TRAVAIL NON TRADITIONNELLE (2003).

115 See e.g. id. and EwING \& HENDY, supra note 112. Note that Ewing and Hendy's proposal appears to be rooted in the British Wages Councils system model.

116 Chris Howell, TRADE UNIONS AND THE STATE: THE CONSTRUCTION OF INDUSTRIAL RELATIONS INSTITUTIONS IN BRITAIN, 1890-2000 88 (2005).

${ }^{117}$ Id. at 89.

118 Order in Council 1305 brought in during the Second World War, replaced by Order in Council 1376, with key provisions subsequently incorporated into Terms and Conditions of Employment Act 1959, 7 Eliz. 2 - 8 Eliz. 2, c. 26, $\S 8$ (Gr. Brit.), and then the Employment Protection Act 1975, 23 Eliz. 2 - 24 Eliz. 2, c. 71, Sch. 11 (Gr. Brit.).

${ }^{119}$ Howell, supra note 116, at 89.
} 
setting by employers and employees, and was clearly not intended to foster workplace parties' independence or to transform into collective bargaining.

A final consideration in this regard is whether sectoral standard-setting mechanisms would satisfy - and are perhaps necessary to satisfy - freedom of association requirements for access to the process of collective bargaining for vulnerable workers for whom access to statutory collective bargaining, absent some form of government support or structure, is effectively nonexistent. ${ }^{120}$

\section{B. Elements of a sectoral standard-setting approach}

Although the three models contain similar elements, the particular approach to each often differed significantly, notably in terms of the breadth of coverage of types of workers and work relationships, breadth of standards addressed, composition of the body, presence and form of dispute resolution for the body, and, enforcement.

\section{i. Breadth of coverage: worker/employee}

Notable among the three systems outlined in this article is that each incorporated broader conceptions of the forms of work relationships that were to be covered, than those included in modern common law and statutory labour and employment systems in Canada. Not only did each cover contractors in addition to more traditional employees, but each had broad understandings of the concept of the employer. The FLSA appears to have been particularly forward-looking in its effort to capture future developments in business organization and to foil business' efforts to avoid regulation through creative structuring of the organization. The FLSA was intended to address the fissured and chain/pyramid structures that have posed such a challenge to modern workplace regulation. ${ }^{121}$

\section{ii. Range of workplace standards}

An important consideration is the range of workplace standards that could be addressed by a sectoral standard-setting body. British Wages Councils (responsible for remuneration, terms and conditions of work and with specific limitations only on holidays and holiday remuneration) and ISA conferences (wages and conditions of work) had broad scope of influence, in contrast with FLSA Wage Boards which were limited to addressing minimum wages. An additional limitation on FLSA Wage Boards discretion was the statutory requirement that minimum wage recommendations be assessed against anticipated effects on employment. ${ }^{122}$ No such mandatory considerations applied under the other systems.

\section{iii. Composition of standard-setting body \& tripartism}

A challenge identified in each system was adequate representation of non-unionized employees. In each case, it appears that unions typically acted as worker representatives. ${ }^{123}$ A second consideration is number of representatives and the overall size of the standard-setting body. Only with FLSA wage boards, which commonly included 20 or more members, was excessive size a concern.

A related issue is the nature of tripartism that is adopted. Each of the three systems examined in this article involve a tripartite structure. ${ }^{124}$ However, they represent different approach to this concept. All

\footnotetext{
${ }^{120}$ In this regard, Canadian Charter case law is of particular interest.

${ }^{121}$ On this point, see Griffith, supra note 86.

122 FLSA 1938, supra note 2, § 8(a).

${ }^{123}$ See Daphne Taras, Reconciling Differences Differently: Employee Voice in Public Policymaking and Workplace Governance, 28 COMP. LAB. L. \& POL'Y J. 167 (2006) (regarding the dilemma of voice for unorganized workers).

${ }^{124}$ Notably, Kate Andrias has recently examined the FLSA as evidence of a history of tripartite approaches to standardsetting in the US and has called for a return to tripartite approaches to employment regulation. Kate Andrias, An
} 
involved representatives of employers and employees, and unions generally ended up acting as employee representatives. However, the systems incorporate different approaches to the third party: Wages Councils utilized independent members, ISA conferences involved an Industrial Standards Officer as representative of the Minister and the State, and the FLSA incorporated "public" representatives.

\section{iv. Autonomy}

A significant difference among the three systems is found in the degree of autonomy they held. British wages councils had statutory authority to issue legally enforceable orders. In contrast both ISA conferences and FLSA wage boards were making recommendations to the government and the government had significant authority to reject or modify the recommendations. The FLSA included several additional features which likely had the effect of limiting wage boards' autonomy: the government could cancel and replace a wage board at any point, wage board minimum wage rates were subject to judicial review that could be initiated by a member of the public, and any resulting wage order was of statutorily limited duration. All three systems provided for a form of public or industrial community transparency, in the form of requiring public hearings, notice or input into proposed orders or recommendations. In the case of the FLSA the input into recommendations included a heavy emphasis on calling evidence and witnesses to inform the boards' recommendation.

One challenge for tripartite sectoral standard-setting bodies is ensuring participation of employers and their representatives. While lack of employer participation was a long-standing problem with ISA conferences, it does not appear that is was a difficulty encountered by British wages councils. ${ }^{125}$ The difference likely lies in the inherent incentive to participate that existed in wages councils. As wages councils had authority to directly issue legally binding orders, if employers did not participate they faced the prospect of becoming subject to orders that they had not participated in developing.

In contrast, under the ISA system, there was little incentive for employers to participate, or to participate constructively. As discussed below, the ISA system provided no way to break a deadlock if a conference was unable to come to agreement. Further, even if employer and employee representatives came to agreement, the Minister could delay, reject, or unilaterally modify the standards. Unlike under the wages council system, there was little prospect under the ISA that if employers did not participate that they would become subject to sectoral standards.

\section{v. Dispute resolution procedure}

Where members of the standard-setting body could not come to agreement, the British wages council system provided for the option of voting-by-sides, and contemplated that independent members would act as tie-breakers. Reportedly, rarely did this have to be resorted to. ${ }^{126}$ The relative autonomy and authority of wages councils demanded some means of breaking deadlocks. This is in contrast to the other systems, which lacked dispute resolution mechanisms.

\section{vi. Enforcement and inspection}

Enforcement and associated investigations are key elements of any scheme of workplace regulation, and any configuration depends on sufficient resources to be effective. The broadest provision for enforcement was provided by the UK wages council system. Government inspections were supplemented by options for

American Approach to Social Democracy: The Forgotten Promise of the Fair Labor Standards Act, 128 YALE L.J. 616 (2019).

${ }^{125}$ INTERCEDE, supra, note 63.

${ }^{126}$ KAHN-FREUND, supra note 8. 
either civil or criminal enforcement. Notably, the civil, contract law, enforcement route arose from the incorporation of works council orders into individual contracts of employment.

Notably the ISA system relied on inspections which were historically underfunded. ${ }^{127}$ Moreover, enforcement was by means of a provincial offences proceeding, which is a costly, cumbersome process which the individual worker is responsible for pursuing.

\section{Conclusion: Returning to the $21^{\text {st }}$ Century}

Segments of the $21^{\text {st }}$ century workplace demonstrate significant parallels to the early $20^{\text {th }}$ century, with severely depressed compensation, poor working conditions, isolated and dispersed workers, with little prospect for access to collective bargaining. For workers in these sectors, a sectoral standard-setting mechanism may be an important opportunity.

This approach is one that various jurisdictions have experimented with in the past. Looking forward, there is value in considering whether elements of these different approaches may be drawn upon to construct a wage board for the $21^{\text {st }}$ century. In particular, consideration may be given to ensuring a broad definition of employee and employer, permitting determination of a wide range of terms and conditions of work, including a dispute resolution mechanism for body decision-making, and incorporating structural features permitting and encouraging the parties to develop capacity to independently negotiate or bargain standards in the future.

127 See InTERCEDE, supra, note 63; Ontario. Committee of Inquiry into the Industrial Standards Act, Report of Committee of Inquiry into the Industrial Standards Act (1963). 